\title{
A Conceptual Approach for Cannibalism Between Goods*
}

\author{
Mauro Maia Laruccia, José Américo Martelli Tristão \\ Pontifícia Universidade Católica de São Paulo and Fundação Armando Alvares Penteado, São Paulo, Brazil \\ Sandra Maria Correia Loureiro \\ Instituto Universitário de Lisboa (ISCTE-IUL), Lisboa, Portugal
}

\begin{abstract}
The launching of a new product is an essential strategy for the survival and success of a company. However, in certain cases, it can reduce the results obtained by other products of the same company. This fact is named “cannibalism”. Following by a review of the literature on cannibalism between goods, this paper outlines a conceptual approach, showing the way it happens, its impacts, and the possibility of its uses as a marketing tool. A new product should, wherever possible, be carefully designed to avoid cannibalizing old products, unless this process is carefully planned. Concludes that creating and launching of new products are critical to companies who want to stand out next to their markets and need to survive over time. A lot of new products launched each year, coupled with the fact that most are line extensions already worked by companies, so we assume that the occurrence of cannibalism is common, or that a significant amount of resources are designed to prevent or dilute it. There is a high probability of transfer of results obtained by established products to new products, since similarity between them.
\end{abstract}

Keywords: cannibalism, new products, marketing, innovation

\section{Introduction}

Among the business strategies of competitive, organizations can highlight the continued development and launch of new products, which occurs by the need to replace a product that no longer provides important benefits to your target audience and the company. Organizations therefore need a continuous flow of development and introduction of new products in markets where they choose to act.

According to Clancy and Shulman (1993), in the area of consumer packaged goods the failure rate of new products is estimated at about $80 \%$, and most of these are composed of line extensions.

Kotler (1998), Semenik and Bamossy (1995), Ries and Trout (2000), and Boone and Kurtz (2009), when claiming the extensions of product line or introducing new products, warning about the risks of cannibalism,

\footnotetext{
* The authors thank Fundação de Amparo à Pesquisa do Estado de São Paulo (FAPESP).

Mauro Maia Laruccia, Doctor in Communication and Semiotics and Master in Business, Economics, Management and Accounting Department, Pontifícia Universidade Católica de São Paulo and Fundação Armando Alvares Penteado.

José Américo Martelli Tristão, Doctor in Public Management, Economics, Management and Accounting Department, Pontifícia Universidade Católica de São Paulo and Fundação Armando Alvares Penteado.

Sandra Maria Correia Loureiro, Doctor in Marketing and International Commerce, Marketing Department, Operation and Management. Instituto Universitário de Lisboa (ISCTE-IUL).

Correspondence concerning this article should be addressed to Mauro Maia Laruccia, Rua Ministro de Godoi, 969 - $1^{\circ}$ (FEA Department), São Paulo 03138-010, Brazil. E-mail: mauro.laruccia@gmail.com.
} 
and competitive dysfunction risk (Yamamoto, Scarpi, \& Laruccia, 2011). Although they believe that cannibalism is an occurrence that can divert business from achieving its goals, therefore, considered a problem that must be controlled, few discuss the causes, consequences, or your dealings with marketing variables. Thus, this study proposes to meet cannibalism among products.

In marketing, cannibalization is the result of the introduction of a new product that will take the market share of an existing product from the same manufacturer/brand. Many disagree with the strategy claiming that diverts the focus of goals, others believe that if were well-planned can lengthen the life cycle for many brands. There are two reasons why the practice of cannibalization: staying ahead of the competition by launching new products/services and prevent the decline in sales. Quoting a bad example of market perception, we have the Kodak that took too long to enter the digital camera market leaving space for competition. The cannibalization strategy is in essence seeking increased sales and creating new business models that can compete with the market constant changes.

\section{Cannibalism in Marketing}

A product line is very small, it can increase profits by adding an item to it, and very large it can increase profits by removing items. That is, there would be no reason to keep products that bring harm or do not contribute significantly to the company's profits. However, this financial approach excludes other important goals of marketing: customer satisfaction, image, market share, leverage other products, customer loyalty etc. (Kotler, 1998).

Cannibalization of products is the process by which a new product gets a share of sales by deviating an existing product. Kerin, Harvey, and Rothe (1978) described the following definition: "while product line extension or repositioning strategies posing minimal risks of failure for product being introduced, potential negative effects on existing products serving existing markets must be considered. These effects can called product cannibalism”. A similar definition is stated by Traylor (1986): cannibalism occurs when sales of a product from a company reduce sales of other. Traylor notes that cannibalism is a problem faced primarily by companies that use multi-brand strategies, since the risk of cannibalism increases as they seek better definitions of new market segments. Therefore, the excessive division of a given market decreases the differences between segments, contributing to the process of cannibalization, since products targeted to a particular segment can attract the public of another segment. However, one can also believe that other brand strategies can contribute to the occurrence of cannibalism, depending on the product and target audiences to whom it is directed and does not seem therefore that the brand policy alone is capable of causing or preventing their occurrences.

Copulsky (1976) stated the "cannibalism result from too close identification of a new product with the launching company’s older products and established markets. New appeals to new market segments will avoid eating one's own market share". Heskett in Kerin et al. (1978) has been defined cannibalization as "the process by which a new product gains a portion of its sales by diverting them from an existing product”.

There are, according to Traylor (1986), two ways to understand cannibalism: with vision focused on the product when a company offers two or more similar products, and market-oriented view, when two or more products of a company competing in the same segment. Kerin et al. (1978) remembered that sales of a new product were coming from sources like new customers, consumers of similar products of competitors and 
consumers of products like the company itself. We can observe that the last of these sources is who triggers cannibalism.

Thus, cannibalism may be understood as an appropriation that a new product is part or all of sales, the sales volume (quantity) of market share, the profits, the spaces intended for distribution channels and/or customer loyalty that normally occur to one or more existing products from the same company (Oliveira, 2000, p. 5). It can be observed cannibalism and its different forms of existence in the four models listed in Figure 1. For a proper understanding of the figures, it should be understood by the competing product sum of the products of competitors targeting the same market segment, and the old products, the products targeted at this segment, belonging to the company that is introducing the new product. The circles represent the sales of products (without scale, just to clarify the ideas described) and the intersections between competing products-new and old should be understood as part of business performance for both floating, i.e., one that also affected of promotional tools, typically reaching consumers who have little loyalty towards a brand or company (Traylor, 1986).

\section{Models of Marketing Cannibalism}

The product line extensions and brand strategies are widely used by companies when launching new products, mostly because of synergy, economies obtained in relation to the establishment of an innovative product and the difficulties in its development, due to the high competitiveness in different markets.

Among the organizations, competitive business strategies focused on growth and survival, we can highlight the continued development and launch of new products that occur both by the need to replace a product that no longer provides important benefits to your target audiences and the companies, as by the need to extend or to create new product lines and brands because of the perception of a market opportunity that enables to achieve increased revenue, profits, profitability, market share, space at the points of sales or customer loyalty. The new product can arise to compose a line already worked for the company as well as part of a new product line. Below is cannibalization models, to thereby better understanding of the impacts associated with each of the model.

The model 1 (see Figure 1) shows a new product introduced by the company that have an old product with an equivalent position. Old product sales cannibalize in the same extent that increase the new product. It is the most dangerous form of cannibalism, because there are no increases in sales, but can be tolerated if the new product is more profitable than the old one.

Model 2 shows cannibalism with less intensity than the one shown in Figure 1, because the new product cannibalize part of the old product (which may be greater or lesser degree) and creates an expanding market where the company operates. This expansion of the market, despite the occurrence of cannibalism, can occur by different attributes that the new product features and by position strategies differently than the old product of the same company.

A third choice of cannibalism, shown in model 3 (see Figure 1) is the occurrence in one part of the old product and a part of a competing product (from another company) also creates a market expansion. It is a situation of greater risk than before, considering that the new product can experience a counterattack from the competition.

In model 4 (see Figure 1), we can see other cannibalism possibility that acts on the company that owns the new product and in competition, with no expansion of the consumer market, presenting, therefore, as a situation 
of greater risk the last one.

Currently, presumed private label brands account for a significant share of sales of retailers, particularly in the area of food. The growth in size and share of own brands can stimulate the development of cannibalism among products, as these produced by industries that have other products on the market with brands of their property and that, attracted by the opportunity to optimize their resources, propose to produce goods exclusively for certain retailers. Once producers do not normally perform the management of these products, but the retailers for which they offer can cannibalize the products cannibalized by this private label and vice versa, this phenomenon is called "indirect cannibalism”.

A second form of indirect cannibalism, but that does not include other companies, is one that occurs with a company's products, as new products developed by a company, we believe there is cannibalism of time and attention of salespeople, managers' products, production and distribution, which can be called pre-cannibalism or institutional cannibalism. In some cases, production can be cannibalized, considering the possibility of a single plant to create different product items.

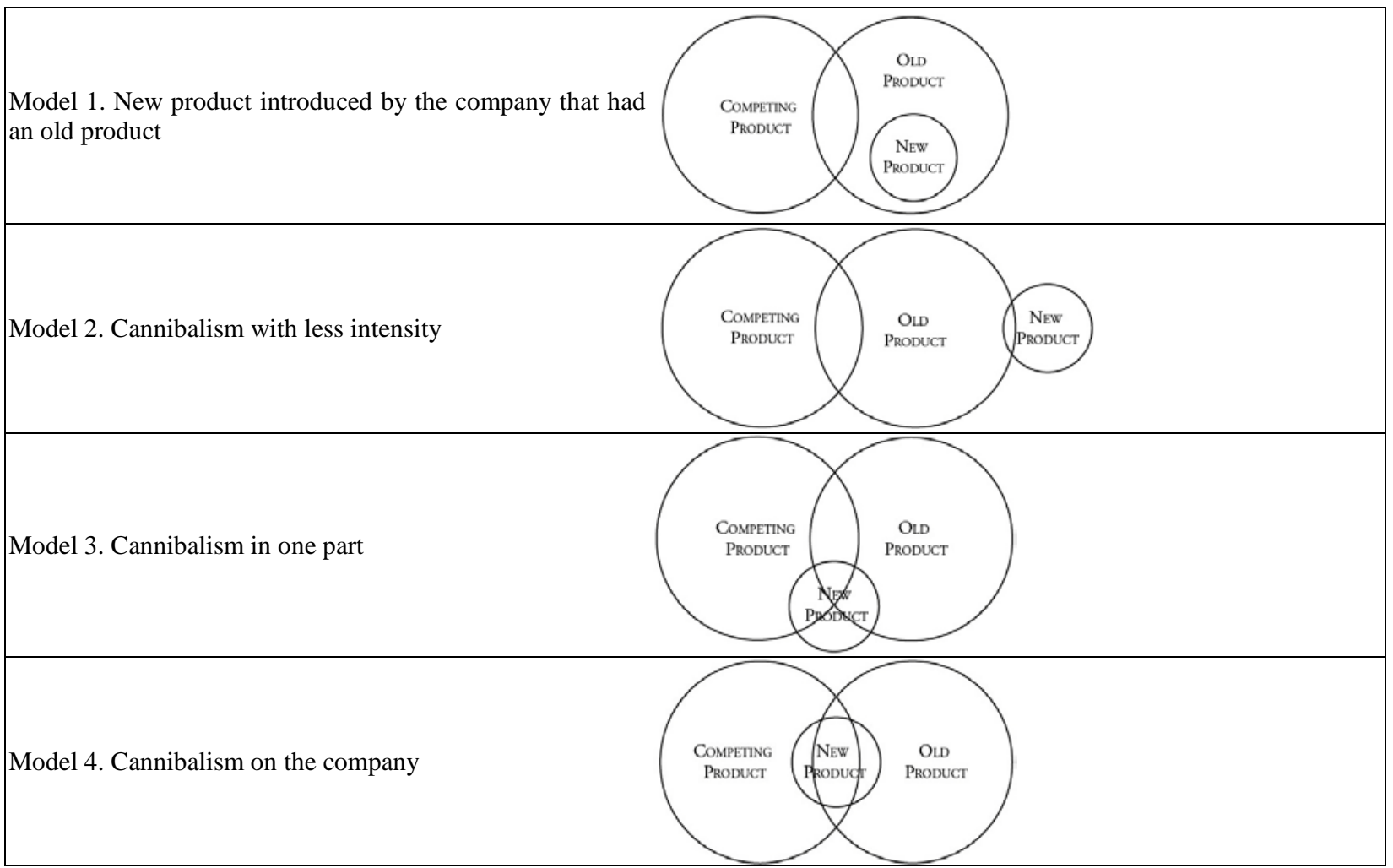

Figure 1. Models of cannibalism. Source: Adapted from Traylor (1986).

\section{Management Marketing Cannibalism}

To prevent the occurrence of cannibalism is to introduce different products to well-defined market segments (Traylor, 1986; Copulsky, 1976). Kein et al. (1978) identified that it was quite common in organizations that can cause cannibalism without benefits. These instances related to top management decisions or the management practices of their products that include: (1) strong top management pressure for growth from new products; (2) 
anxiety with developing a complete line of products in an effort to gain increases in the overall market share, in a product class; (3) inadequate positioning of new products; (4) not realistic or excessive market segmentation resulting in segments that demands similar product attributes or end-user needs; and (5) destructive promotional efforts reflected in sales representatives' overemphasis on new brands and neglect of exiting products.

Depending on the strategies and objectives developed by the company to introduce a new product on the market, may be brought in three different strategies that provide no cannibalism: (1) attacking the competition without market expansion; (2) expanding the market to competition with attack; and (3) expanding the market to competition without attack (see Figure 2).

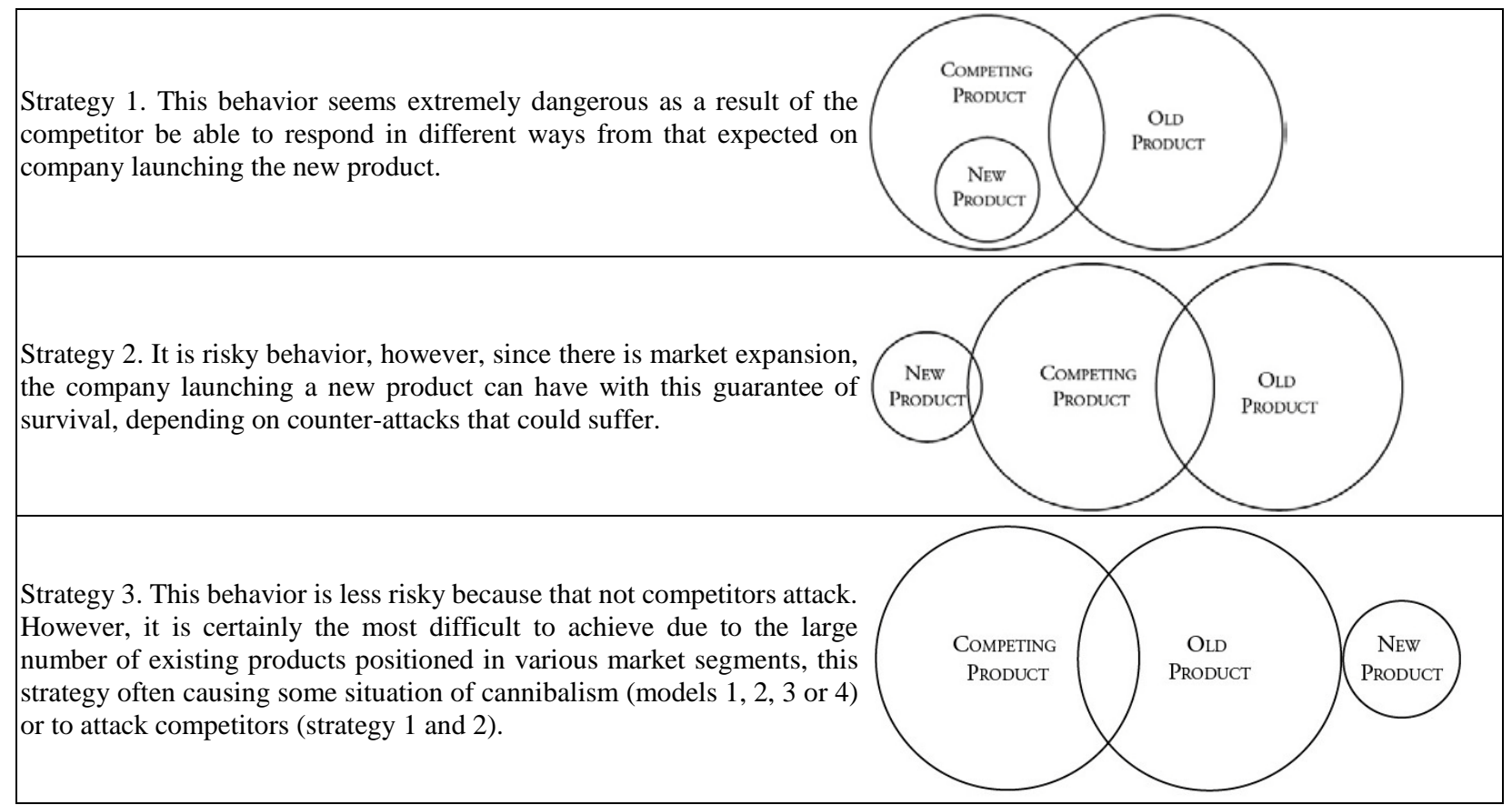

Figure 2. Models of cannibalism strategy. Source: Adapted from Traylor (1986).

Cannibalism sometimes can develop a new business model, as the case of newspapers trying to charge for reading the contents on tablets and smartphones (Model 1, Strategy 1 and 2). Instead of newspaper consolidation described by Sedgwick (1928) as process Malthusianism with an operation that suppresses some newspapers and in order to have better chances to survival. Álvares (2012) reminded that the New York Times had about 500,000 subscribers who pay for any of the three types of digital packages offered $\$ 20$ per month on average. Charging for digital contents, implemented last year, should have occurred before. The amount of $40 \%$ of the newspaper audiences would be willing to pay for something. A year after the recovery, the New York Times digital subscription model proved to be innovative. But he warned that the changes in the model may not involve the abandonment of the basic premises of good journalism. On the other hand, the Indian Raju Narisetti, Digital Network managing editor of The Wall Street Journal defended the pay wall system in a way that does not cannibalize the print newspaper (Manzano, 2012). In Brazil, the newspapers are developing new products, as the "Globo a Mais" with Globo content exclusive to iPad was released reading calmly typical newspaper, accompanied by a multimedia journalism. Other journal develops strategies such as the creation Information 
Technology (IT) team exclusive for digital content in “Zero Hora” newspaper.

Otherwise to reflection, Flavián and Gurrea (2007) confirmed that readers motivated by aspects related essentially to differential attributes of the internet versus traditional channels perceive them both as information conduits and not as substitutive products. Meanwhile, motivations that could be satisfied through both channels positively affect the level of perceived substitutability between digital and traditional newspapers. Nevertheless, readers prefer reading a newspaper in the physical medium, for entertainment.

According to Merunka (2010), in a sales environment, cannibalism refers to the extent to which sales of one product arise at the expense of other products from the similar brand or sold by the same company. Margins and sales generated through new-product introductions may not result in increased whole sales or revenues if these new products cannibalize existing products. Yet, the concepts of cannibalism should be extended to company's current investments and capabilities, including their willingness to cannibalize, which refers to the firm's disposition to cannibalize its prior investments and current organizational know-how beyond the sales of its current products. Willingness to cannibalize pushes radical product innovation, which implies that the cannibalization of current products and technologies may be a desirable strategy that favors radical innovations and new-product introductions and determines firm's long-term success in the marketplace like some newspaper companies. The concept of cannibalism thus is important for brand management and innovation management, as well as for channel management.

\section{Final Considerations}

Creating and launching of new products are critical to companies who want to stand out next to their markets and need to survive over time. A lot of new products launched each year, coupled with the fact that most are line extensions already worked by companies, so we assume that the occurrence of cannibalism is common, or that a significant amount of resources are designed to prevent or dilute it. There is a high probability of transfer of results obtained by established products to new products, since similarities between them.

This conceptual study can better understand cannibalism, which may be either a question or dysfunction that contributes negatively to the company - to narrow the results to negatively impact on the optimization of resources used-or contribute to a solution or alternative strategy to achieve objectives. A new product should, wherever possible, be carefully designed to avoid cannibalizing older products, unless this process is carefully planned. It is recommended that further studies should be applied to products and services in order to test the cannibalism models and strategies.

\section{References}

Álvares, D. (2012). Jornais debatem cobrança por conteúdo. O Estado de S. Paulo (p. A8). Sao Paulo.

Boone, L. E., \& Kurtz, D. L. (2009). Contemporary marketing. Mason, Ohio: Cengage South-Western.

Clancy, K. J., \& Shulman, R. S. (1993). The marketing revolution: A radical manifesto for dominating the marketplace. New York: Harper Business.

Copulsky, W. (1976). Cannibalism in the Marketplace. Journal of Marketing, 40(4), 103-105.

Dhar, S. K., \& Hoch, S. J. (1997). Why store brand penetration varies by retailer. Marketing Science, 16(3), 208.

Flavián, C., \& Gurrea, R. (2007). Perceived substitutability between digital and physical channels: The case of newspapers. Online Information Review, 31(6), 793-813. 
Kerin, R. A., Harvey, M. G., \& Rothe, J. T. (1978). Cannibalism and new product development. Business Horizons, $21(5), 25$. Kotler, P. (1998). Marketing and electronic marketing and the internet. Australia: Prentice Hall.

Lomax, W. (1996). The measurement of cannibalization. Marketing Intelligence \& Planning, 14(7), 20-28.

Manzano, G. (2012). Editor sugere calma com cobrança de conteúdo na rede. O Estado de S. Paulo. Retrieved August 22, 2012, from http://www.estadao.com.br/noticias/nacional,editor-sugere-calma-com-cobranca-de-conteudo-na-rede,920072,0.htm

Merunka, D. R. (2010). Cannibalism. In J. Sheth, \& N. Malhotra (Eds.), Wiley International Encyclopedia of Marketing. Chichester, UK: John Wiley \& Sons, Ltd..

Mitchell, A. (1998). Brands must act to stop cannibals eating them up. Marketing Week, 21(1), 32.

Oliveira, B. A. C. (2000). Canibalismo entre produtos: um estudo exploratório dos fatores de marketing que contribuem para a sua ocorrência em indústrias alimentícias paulistanas (Master dissertation, Universidade Mackenzie).

Ries, A., \& Trout, J. (2000). Positioning: The battle for your mind. London: McGraw-Hill.

Sedgwick, J. H. (1928). Newspaper cannibalism. North American Review, 225, 415-419.

Semenik, R. J., \& Bamossy, G. J. (1995). Principles of marketing: A global perspective. Cincinatti, O.H.: South-Western College Publishing.

Traylor, M. B. (1986). Cannibalism in multibrand firms. Journal of Consumer Marketing, 3(2), 69.

Yamamoto, E. Y., Scarpi, M. J., \& Laruccia, M. M. (2011). Competitive dysfunctions: The contribution for services of ophthalmology clinics. Journal of Management and Strategy, 2(4), 64-74. 